\section{A Cornish Headland Fortified Site}

Some interesting results, it may be expected, will emerge from an archæological exploration of a Cornish headland fortified site, which has been in progress under the direetion of Dr. R. E. Mortimer Wheeler during the fortnight ending on April 24, when digging ceased. The site comprises a series of hut-circles within an enclosed area on Gurnard's Head, near Falmouth. The purpose of the investigation is to endeavour to trace evidence of connexion in the first century B.c. between these Cornish headland forts and the contemporary or earlier inhabitants of the sites on the south-west coast of Brittany examined by Dr. Wheeler's expedition last year. The fortified enclosure here is formed by three ditches running across the neck of the peninsula, protecting it from attack on the landward side. The hut-circles, according to a report in the Western Independent of April 23, begin close to the inner rampart, of which the wall was in three steps, recalling the structure of the hill-fort of Kercaradec, near Quimper in Brittany, which has been described by Dr. Wheeler as fortified by three lines, with an inner rampart faced by dry stone walling, of which the innermost facing was stepped in three stages and surmounted by a timber palisade. A feature of the construction of the hut-circles, which is said particularly to have impressed the excavators, is the large size of the placed wall-stones. The discovery of a spindle whorl of pottery attests the presence of women, even though the hut-circles do not appear to have been places of permanent occupation. A number of sea-rolled stones include sling-stones; and two sherds of pottery show fragments of the spiral decoration of the first century B.c. A sherd with 'duck' pattern recalls a find at Chun Castle, four miles away, made by Mr. Leeds in a fort resembling the forts of northern Spain, and interpreted by him as a relic of connexion due to ancient metal working.

\section{Dermatology and Folk-lore}

AT a meeting of the St. John's Hospital Dermatological Society on April 26, Dr. J. D. Rolleston read a paper on this subject. After a few remarks on folklore in relation to skin diseases generally, in which he alluded to their supposed causation, prophylaxis and treatment, he dealt with the individual skin diseases with which folk-lore was most concerned. No skin disease, he said, or indeed disease of any kind, had received so much attention in folk medicine as warts, the literature on the subject even exceeding that on whooping cough or 'ague'. Next in importance in popular estimation came shingles, and then baldness, boils, burns, cosmetic defects such as freckles and wrinkles, congenital abnormalities, ringworm, urticaria, eancer of the skin and chilblains, in the order named. As in his previous paper on "Folklore and Medicine" (see NATURE, January 21, p. 111) Dr. Rolleston discussed the various preventive and therapeutic measures used in folk-lore under the following headings: (1) transfer of the disease to other persons, animals or inanimate objects; animal and plant remedies; (3) religious influences, including invocations to patron saints; (4) the healing power of water in the form of wells, springs, fountains and streams; (5) the mystical power of odd numbers; (6) repellent and disgusting remedies, including coprotherapy, for the object of driving out the evil spirit supposed to be the cause of the disease ; (7) miscellaneous cures, such as the doctrine of signatures, the influence of the moon and fasting saliva.

\section{Archæology and the Bible}

The striking manner in which post-War archæological investigation in the Near and Middle East has contributed to Biblical studies is concisely reviewed by Prof. S. H. Hooke in "Archæology and the Old Testament" (London, Thomas Murby and Co., 1938. Pp. 32. 6d. net), one of an excellent little series entitled "After 400 Years", which deals with various aspects of the Bible in the light of modern scholarship. Whereas at one time the efforts of the archæologist in the interests of Biblical studies were directed mainly to the search for texts which might confirm the Hebrew record, modern excavations in Mesopotamia, in Syria and in Palestine or Egypt have not merely provided a measure of corroboration for the Biblical narrative of the course of events, but also-and to many this may seem of major importance- they have given the Scriptural records a historical setting and cultural background, both within the boundaries of Palestine and in relation to neighbouring peoples and empires, which has elucidated a multitude of obscurities in the Biblical historical narrative as well as in tradition, in ritual and in belief. Thus Prof. Hooke, speaking of the recent investigations of Sir Leonard Woolley at Ur, of Dr. Dorothy Garrod in Palestine, and of others elsewhere, is able to say that "during the last thirty years archæology has reconstructed the stage . . . on which the drama of the history of the Hebrew people was played . . . those great ancient civilizations, which surrounded and profoundly influenced that small country of Canaan". Making this his starting point, he passes on to show the manner in which the attitude of instructed opinion on Biblical questions has been profoundly modified by recent discovery in regard to the history of writing and its beginnings, early law and legal codes, the conquest of Palestine, the religion, ritual, and mythology of Canaan, the condition of Palestine in the time of the Lachish letters, the Hittites and their empire, and like matters.

\section{New Air Speed Record}

THE absolute air speed record of more than 463 miles an hour, set up by Herr Dieterle in Germany recently (reported in NATURE of April 15, p. 633), has now been broken. Herr Wendel, flying a Messerschmitt Me.109.R. fighter fitted with a Mercedes-Benz engine and a V.I.M. metal airscrew, claims to have attained a speed of 755 kilometres (469.11 miles) an hour. Reports claim that this aircraft is a new type of fighter, and the published rating of the engine is 